\title{
PRELIMINARY X-RAY DIFFRACTION AND RAMAN SPECTROSCOPY STUDIES ON BIS(L-THREONINE) NICKEL(II) MONOHYDRATE CRYSTAL
}

\author{
Melo, E. B. ${ }^{1}{ }^{*}$; Lima Jr., J. A. ${ }^{2}$; Santos, C. C. ${ }^{1}$; de Menezes, A. S. ${ }^{1}$ \\ ${ }^{1}$ Departamento de Física, CCET, Universidade Federal do Maranhão, São Luís, MA, Brazil \\ ${ }^{2}$ Departamento de Física, Universidade Federal do Ceará, Campus do Pici, Fortaleza-CE, Brazil \\ *ezequinewton@gmail.com
}

Copper like all metals forms coordination complexes with ligands and stable complexes with amino acids. One of those complexes is $\mathrm{Bis}(\mathrm{L}-$ threonine $)$ cooper(II). $\mathrm{H}_{2} \mathrm{O}\left(\mathrm{Cu}\left(\mathrm{C}_{4} \mathrm{H}_{8} \mathrm{NO}_{3}\right)_{2} \cdot \mathrm{H}_{2} \mathrm{O}\right)$ that $\left(\$ \mathrm{C}_{-}\{6\} \mathrm{H}_{-}\{9\} \mathrm{O}_{-}\{2\} \mathrm{N}_{-}\{3\} . \mathrm{HCl}_{-} \mathrm{H}_{-}\right.$ $\{2\} \mathrm{O} \$$ ) crystallizes in the monoclinic structure with 2 molecules by unit cell, space group $\mathrm{P} 2$ and cell parameters $a=11.02(2) \AA, b=4.90(1) \AA, c=11.16(2) \AA$ and $\beta=93.5(5)^{\circ}$. In this work, we used the nickel instead of copper to grow the $\mathrm{Bis}\left(\mathrm{L}\right.$-threonine)nickel(II) Monohydrate $\left(\mathrm{Ni}\left(\mathrm{C}_{4} \mathrm{H}_{8} \mathrm{NO}_{3}\right)_{2} \cdot \mathrm{H}_{2} \mathrm{O}\right)$. In order to obtain this crystal, 1 mol of $\mathrm{NiCl}_{2} \cdot 6 \mathrm{H}_{2} \mathrm{O}$ was added to an aqueous solution with 2 mols of L-thronine. $\mathrm{NaOH}$ was added to this solution to obtain a solution with $\mathrm{pH}=8$. Beautiful small plate-like blue crystals were grown by slow evaporation method after keeping the temperature constant at $30^{\circ} \mathrm{C}$. X-ray powder diffraction measurements of the $\mathrm{Bis}\left(\mathrm{L}\right.$-threonine)nickel(II). $\mathrm{H}_{2} \mathrm{O}$ crystal showed a pattern similar to the Bis(L-threonine)copper(II). $\mathrm{H}_{2} \mathrm{O}$ crystal but not similar enough to perform the Rietveld refinement using the cif file of the copper crystal. To study the behavior of nickel crystal as a function of the temperature, powder X-ray diffraction measurements were carried out in a Bruker D8 Advance diffractometer using an Anton Paar temperature chamber (TTK 450). For the measurements in the range $-190^{\circ} \mathrm{C}$ to $110^{\circ} \mathrm{C}$ it was observed shifts in the peaks. For the measurements above $110^{\circ} \mathrm{C}$ it was observed the appearing and disappearing of peaks, characterizing a structural phase transition. Raman Spectroscopy measurements at room temperature and as a function of temperature were also performed.

Financial support: CNPq and FAPEMA. 